\title{
SEP 121962
}

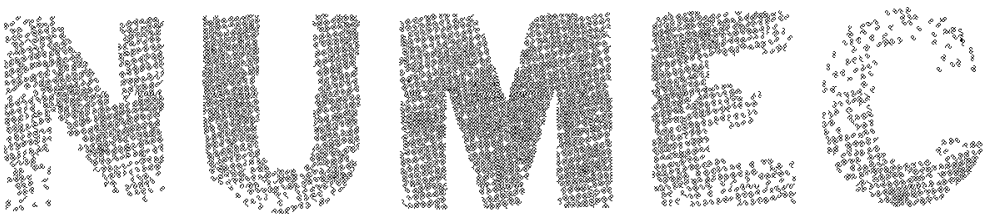

Nuclear Materials and Equipment Corporation

Apollo, Pennsylvania

Telephone GRover 2-8411

Cable NUMEC

NUNEC P-44

August 5, 1962

Mr. Morris Goldberg, Director

Contracts Division

New York Operations Office

U. S. Atomic Energy Commission

376 Hudson Street

New York 14, New York

Attention: Mr. Seymour Zirin, Contracts Administrator

Subject: CONTRACT AT $(30-1)-2389$

"DEVELOPMENT OF PLUTONIUM-BEARING FUEL MATERIALS"

MONTHLY PROGRESS LETTER FOR MONTH OF JULY 1962

Gentlemen:

NUMEC herewith transmits the Monthly Progress Letter for July 1962 covering wrok performed under Contract $\operatorname{AT}(30-1)-2389$.

Major effort during this month was expended on the preparation and characterization of samples scheduled for in-pile screening tests. Also, calculations were completed on the determination of the amounts of boron steel required to reduce General Electric Testing Reactor (GETR) Trail Cable Facility fluxes to the levels desired for the various test specimens. Final capsule assembly will be performed as soon as the boron steel is received and the final capsule design is approved by GETR .

Installation of hot cell and hot metallographic cell alpha box equipment is continuing in order to have these facilities in operation when the inradiated specimens are returned for post-irradiation examination. A second-hand Bausch and Lomb metallograph has been procured and is being modified to permit examination of the irradiated specimens.

Effort is continuing on the preparation and evaluation of $\mathrm{UO}_{2}-\mathrm{PuO}_{2}$ coprecipitated by relatively long, continuous processing. Three additional preparation runs were completed this month under the conditions set forth in Table I. To evaluate the effect of $\mathrm{Pu} / \mathrm{U}$ ratio over a broader range, one run was made with $\mathrm{UO}_{2}-35 \mathrm{w} / 0 \mathrm{PuO}_{2}$.

s report was prepared as an account of Government sponsored work Neither the Untted A, nor the Commission, nor any pergon actung on behalf of the Commission racy, completeness, or usafulness of the informetessed or implited, with respect to the accuof any information, apparatus, method, or process digclosed in this report may not infringe privately ownod rights, or B Assumes any liablities with respect to the use of, or for damages resulting from the As used in the apparatus. method, or process disclosed in this report

Ased in the alove, "person acting on behalf of the Commission" includes any om Buch expontractor of the Commission, or employee of such contractor, to the extent that such employee or contractor of the Commission, or employee of such contractor prepares, with the Com, or provides access to, any information pursuant to bis employment or contraci

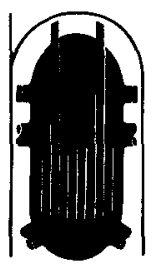




\section{DISCLAIMER}

This report was prepared as an account of work sponsored by an agency of the United States Government. Neither the United States Government nor any agency Thereof, nor any of their employees, makes any warranty, express or implied, or assumes any legal liability or responsibility for the accuracy, completeness, or usefulness of any information, apparatus, product, or process disclosed, or represents that its use would not infringe privately owned rights. Reference herein to any specific commercial product, process, or service by trade name, trademark, manufacturer, or otherwise does not necessarily constitute or imply its endorsement, recommendation, or favoring by the United States Government or any agency thereof. The views and opinions of authors expressed herein do not necessarily state or reflect those of the United States Government or any agency thereof. 


\section{DISCLAIMER}

Portions of this document may be illegible in electronic image products. Images are produced from the best available original document. 
NUMEC P 244

Table I

Preparation Data for

Continuous Coprecipitation of $\mathrm{UO}_{2}-\mathrm{PuO}_{2}$

\begin{tabular}{|c|c|c|c|}
\hline Run Identification & $297 \mathrm{Pu}-18$ & 297 Pu-19 & $297 \mathrm{Pu}-20$ \\
\hline $\begin{array}{l}\text { End Product } \\
\text { Feed Composition: } \\
\qquad \mathrm{g} \mathrm{U} / \mathrm{I} \\
\mathrm{g} \mathrm{Pu} / \mathrm{I} \\
\mathrm{H}^{+}, \mathrm{molaritv} \\
\text { Feed Flow Rate, I/hr } \\
\text { Ammonia Concentration, } \\
\text { molarity } \\
\text { Ammonia Flow Rate I/hr } \\
\text { Holdur Time, minutes } \\
\text { Total Number Throughputs } \\
\text { Drying Temperature, } \mathrm{C}\end{array}$ & $\begin{array}{c}\mathrm{JO}_{2}-0.5 \mathrm{w} / \mathrm{O} \mathrm{PuO}_{2} \\
109.4 \\
0.6 \\
1.0 \\
1.2 \\
14.5 \\
0.3 \\
32.4 \\
20 \\
110\end{array}$ & $\begin{array}{c}\mathrm{OO}_{2}-35 \mathrm{w} / \mathrm{OPuO} \\
73.5 \\
36.3 \\
1.0 \\
7.2 \\
34.5 \\
0.3 \\
30.0 \\
10 \\
180\end{array}$ & $\begin{array}{c}\mathrm{UO}_{2-12.5} \mathrm{w} / \mathrm{O} \mathrm{PuO}_{2} \\
87.5 \\
12.5 \\
1.0 \\
1.1 \\
14.5 \\
0.3 \\
32 \\
16 \\
180\end{array}$ \\
\hline
\end{tabular}

Precipitates produced during the startup and shutdown portions of the runs were segregated from the steady-state material. Further, to allow assessment of the effects of conversion conditions, the steady-state portions of the runs were divided into portions of $180 \mathrm{~g}$ each and then converted to mixed axide under different conditions. To allow product comparison with steadystate materials, the startup and shutdown portions were also converted. Characterization of these samples is expected to be completed next month. Preliminary results indicate that $\mathrm{PuO}_{2}-\mathrm{OO}_{2}$ powder derived from the $\mathrm{ADJ}-\mathrm{Pu}(\mathrm{OH})_{4}$ precipitate obtained at the beginning or middle of a run has a significantly lower surface area than powder derived from the precipitate obtained at the end of 8 to 10 hours of continuous operation. The available data also indicate that at least part of this difference may be attributed to minor variations in precipitate treatment prior to reduction.

Steady-state intermediate production run 297 Pu-18 was used to study the contribution of possible reduction of ADU by the ammonia evolved during the initial stages of mixed oxide precursor conversion. Wet filter cakes were dried a relatively low temperature of $110^{\circ} \mathrm{C}$ for three days to avoid premature thermal decomposition during the drying step. To determine whether or not self-reduction occurred, large and small charges of the precursor were thermally decomposed in $\mathrm{N}_{2}$ using a rapid temperature rise from ambient to operating conditions. Separate but similar size charges were thermally decomposed in commercially-purified $\mathrm{N}_{2}$ using a slow temperature rise from amhient, to onerating temperature according to conditions summarized in Table II. Weighed samples were calcined in air at $900^{\circ} \mathrm{C}$ and then reweighed to determine the oxygen to metal ratio. 
NOMEC P- 444

Table II

Conditions for Thermal Decomposition of

$\mathrm{UO}_{2}=0.5 \mathrm{w} / 0 \quad \mathrm{PuO}_{2}$ Precursor

\begin{tabular}{|c|c|c|c|c|}
\hline $\begin{array}{c}\text { Charge size } \\
(g)\end{array}$ & $\begin{array}{l}\text { Rate of } \\
\text { Temp. Rise } \\
\text { (Ambient to } \\
\text { Conversion) } \\
(\text { C } / \text { min) }\end{array}$ & $\begin{array}{l}\text { Conversion } \\
\text { Temperature } \\
\left({ }^{\circ} \mathrm{C}\right)\end{array}$ & $\begin{array}{l}\text { Hold } \\
\text { Time } \\
\text { (min) }\end{array}$ & $\begin{array}{l}\text { Oxygen to } \\
\text { Metal Ratio }\end{array}$ \\
\hline 64 & 12 & 740 & 80 & 2.66 \\
70 & 2 & 740 & 80 \\
429 & 740 & 80 & 2.66 \\
433 & 2 & 740 & 80 & 2.66 \\
\hline
\end{tabular}

The value of the oxygen to metal ratio was 2.66 in every case, indicating that the product of the conversion was $\mathrm{U}_{3} \mathrm{O}_{8}$ and that no significant amount of self-reduction had occurred under the conditions used.

Sintering studies on $\mathrm{PuO}_{2}$ and mixed oxide $\mathrm{NO}_{2}-\mathrm{PuO}_{2}$ are also continuing to allow assessment of the effect of the various process variables that enter into the precipitation operation. Standardization of pellet fabrication techniques are being contemplated to allow more meaningful interpretation of the data. Pure $\mathrm{PuC} 2$ pellets that were sintered in vacuum at a high temperature $(100-20090 \mathrm{C})$ reacted considerably with the pellet supports, tantalum and magnesium. No evaluation of the sinterability at these temperatures could be made because of these reactions. Metallographic examination of the $\mathrm{PuO}_{2}$, the support metal, and the reaction products is under way.

Effort is also continuing on the development of techniques for producing spherical particles by mechanical agglomeration and sintering, and by plasma torch fusion. Wet agglomeration methods have been attempted during this period. Initial trials indicate that green agglomerates having densities as high as $5.1 \mathrm{~g} / \mathrm{cc}$ can thereby be obtained; in comparison dry agglomeration yielded green densities in the range 3.5 to $3.8 \mathrm{~g} / \mathrm{cc}$. Subsequent sintering of these agglomerates at $1550-1600^{\circ} \mathrm{C}$ for 2 hours in air resulted in densification to $10.4 \mathrm{~g} / \mathrm{cc}$. The primary purpose of the plasma torch fusion studies performed during this month was to obtain complete fusion of mixed oxide particles. While pure $\mathrm{PuO}_{2}$ or $\mathrm{JO}_{2}$ can be readily fused to high density, mixed crystal particles are generally only surface polished when run through the torch under similar conditions. Tuns with a plasma nozzle designed to gain longer residence time within the high temperature torch zone have indicated promise in this direction. 


\title{
NUMEC P- 44
}

Due to the release of the new uranium price schedule, all previously performed fuel cycle economics analyses have been revised. The results show that no major conclusions need be altered due to the revision in uranium prices.

\author{
Very truly yours,

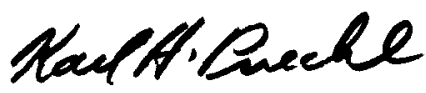 \\ Karl H. Puechl \\ Acting Director \\ Advanced Materials Center
}

KIIP/enk 
NUMEC P-44

\section{EXTERNAL DISTRIBUTION}

U. S. Atomic Energy Commission, New York Operations Office

M. Goldberg, Contracts Division

S. Zirin, Contracts Division

V. Siuta, Research and Development Division

H. S. Potter, Patent Group

U. S. Atomic Energy Commission, National Laboratories

R. Grube - Washington

J. M. Simmons, Division of Reactor Development - Washington (2)

G. W. Wensch - Washington

Reports and Statistics Branch - Washington

F. Foote, Argonne National Laboratory

H. Young, Argonne National Laboratory (4)

E. J. Kreh, Westinghouse-Bettis Atomic Power Laboratory

E. A. Eschbach, Hanford Atomic Products Operations

E. A. Evans, Hanford Atomic Products Operations

J. Musser, Hanford Atomic Products Operations

I. D. Thomas, Hanford Atomic Products Operations

O. J. Wick, Hanford Atomic Products Operations

W. Cashin, Knolls Atomic Power Laboratory

H. Rizzo, Lawrence Radiation Laboratory

R. D. Baker, Los Alamos Scientific Laboratory

L. B. Jones, Mound Laboratory

Office of Technical Information Extension, ORNL

U. S. Atomic Energy Commission, Contractors

R. W. Dayton, Battelle Memorial Institute

R. F. Dickerson, Battelle Memorial Institute

K. Taylor, Carborundum Company

C. Cohen, General Electric Company-San Jose

A. Strasser, Nuclear Development Corporation of America

R. W. Hartwell, Power Reactor Development Company

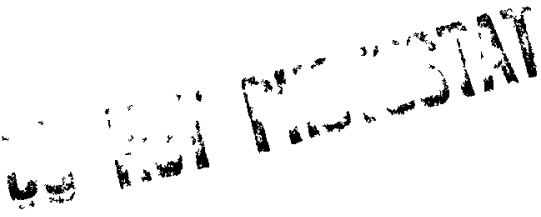


NUNEC $P-44$

\section{NUMEC DISTR IBUTION LIST}

\begin{tabular}{|c|c|}
\hline 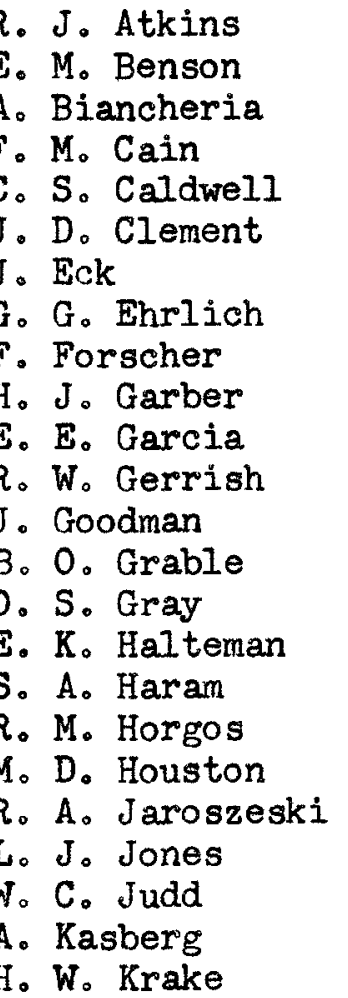 & $\begin{array}{l}\text { J. C. Limpert } \\
\text { D. C. McKissick } \\
\text { J. Marley } \\
\text { O. Menis } \\
\text { J. F。 Miles } \\
\text { I. P. Pepkowitz } \\
\text { K. H. Puechl } \\
\text { P. Rey } \\
\text { W. J。 Ross } \\
\text { T Roth } \\
\text { J. Ruzbacki } \\
\text { A. T. Sabo } \\
\text { J. Scott } \\
\text { Z. M. Shapiro } \\
\text { F。 Shipko } \\
\text { J. Stoner } \\
\text { R. S. Swain } \\
\text { J. M. Toman } \\
\text { M. M. Turkanis } \\
\text { B. Vondra } \\
\text { L. Weber } \\
\text { A. M. Weis } \\
\text { M. Zambernard } \\
\text { Library }\end{array}$ \\
\hline
\end{tabular}

